\title{
Study of Increasing Apron Facilities of Husein Sastranegara Airport Bandung
}

\author{
Fuad Hasan \\ Department of Civil Engineering, Widyatama University, Indonesia
}

Copyright $\subseteq 2019$ by authors, all rights reserved. Authors agree that this article remains permanently open access under the terms of the Creative Commons Attribution License 4.0 International License

\begin{abstract}
Husein Sastranegara International Airport is an airport located in Bandung, West Java, Indonesia. In addition to serving the community, the airport is also one of the military air force bases. Increased economic growth after the monetary crisis and the emergence of many Low-Cost Airline (LCA) will trigger an increase in air transport movements at Husein Sastranegara airport, which in the next stage returns the movement pattern to the pattern of movements before the 1997 crisis, namely patterns that are in line with regional economic growth Bandung Raya (Bandung City and Regency, Sumedang Regency and Cimahi City). It is believed that the current airport facilities will not be able to accommodate requests during peak hours in the future, so it needs evaluation and analysis of facility requirements and facility development planning up to the year of development limits.
\end{abstract}

Keywords Airport, Evaluation, Facility Development

\section{Introduction}

The airport is a vital means of transportation for inter-island and inter-country relations in Bandung. Husein Sastranegara International Airport is an airport located in Bandung, West Java, Indonesia. In addition to serving the community, the airport is also one of the military air force base. If viewed on a map, the public airport will be seen in the south west and military in the south east left. On the north side of the runway, the hangars owned by PT. Dirgantara Indonesia can be seen.

Increased economic growth after the monetary crisis and the emergence of many Low-Cost Airline (LCA) will trigger an increase in air transport movements at Husein Sastranegara airport. It is believed that the current airport facilities will not be able to accommodate requests during peak hours in the future, so that it needs an analysis of facility requirements and facility development planning up to the year of development limits.

\section{Apron}

An apron is a defined area intended to accommodate aircraft for purposes of loading and unloading passengers, mail or cargo, fuelling and parking or maintenance. The apron is generally paved but may occasionally be unpaved; for example, in some instances, a turf parking apron may be adequate for small aircraft.[1][3]

\section{Methodology}

The process of completing this research can be explained as follows:

1. Identify Apron

2. Data Collection: Primary and Secondary Data

3. Evaluation of Existing Apron: geometric and capacity of the existing apron

4. Analysis of Traffic Forecast Air Transport

5. Evaluation of Future Apron Performance: geometric conditions of aprons and future apron capacity.

6. Results of Evaluation of Existing and Future Apron Performance

7. Analysis and Discussion

8. Conclusions and suggestion

\section{Analysis and Discussion}

\subsection{Analysis of Air Transport Traffic Forecasting}

The Apron of Husein Sastranegara Airport has dimensions of $\pm 36890 \mathrm{~m}^{2}$ with details $\pm 9750 \mathrm{~m}^{2}$ for rigid pavement and $\pm 27140 \mathrm{~m}^{2}$ for flexible pavement. This Apron has 8 parking stands, can accommodate 8 aircraft with Boeing B737-500 or 7 Airbus A320 aircraft types. The apron configuration used by Husein Sastranegara Airport uses a linear / frontal concept system (front row of the arrival gate). 


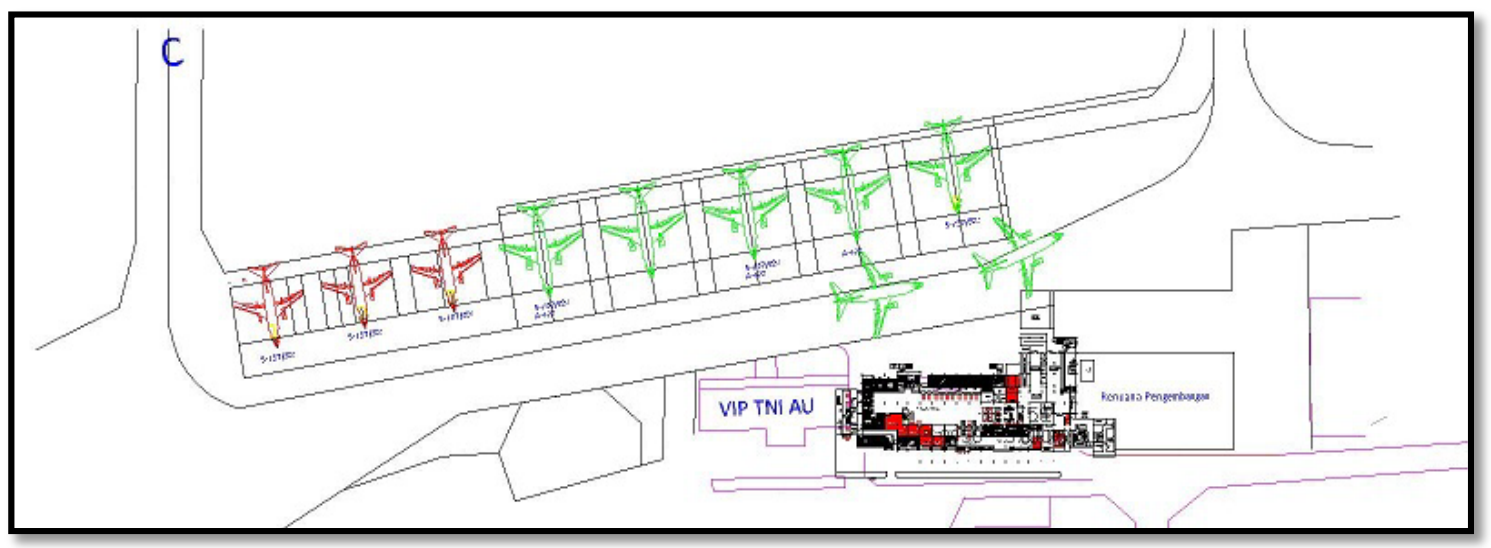

Figure 1. Apron configuration and parking type

The primary and secondary data that have been obtained are added with parameters that have been determined and analyzed, to be evaluated and analyzed to obtain the upcoming apron performance according to the planned year.

Forecasting is intended to calculate the possibility of increasing the number of passengers and the number of aircraft in the future with various parameters used to support forecasting as accurately as possible.

The model used in forecasting is the Trend Analysis model in the form of a Linear Regression method (straight line curve). This model is examined based on data on the movement of passengers, baggage and cargo against the Constant GRDP in year of 2000 and population growth. The results of linear regression analysis between GRDP and population with passengers, baggage and cargo are shown in table 1 and table 2 below.

Table 1. Results of Regression Analysis (GRDP)

\begin{tabular}{|c|c|c|c|}
\hline & Equation & $\mathbf{R}^{2}$ & $\mathbf{R}$ \\
\hline Passenger & $\mathrm{y}=29.47 \mathrm{x}-29492$ & 0.695 & 0.834 \\
\hline Baggage & $\mathrm{y}=320.75 \mathrm{x}-4347229.99$ & 0.900 & 0.951 \\
\hline Cargo & $\mathrm{y}=44.36 \mathrm{x}-57124$ & 0.850 & 0.922 \\
\hline
\end{tabular}

Table 2. Results of Regression Analysis (Population)

\begin{tabular}{|c|c|c|c|}
\hline & Equation & $\mathbf{R}^{\mathbf{2}}$ & $\mathbf{r}$ \\
\hline Passenger & $\mathrm{y}=1.54 \mathrm{x}-3,150,125.07$ & 0.470 & 0.686 \\
\hline Baggage & $\mathrm{y}=18.42 \mathrm{x}-39,200,511.37$ & 0.740 & 0.860 \\
\hline Cargo & $\mathrm{y}=2.68 \mathrm{x}-5,709,390.38$ & 0.770 & 0.877 \\
\hline
\end{tabular}

The results of the analysis using the Trend Analysis Model in the form of a linear regression method show that the correlation value of the regression of passengers, baggage and cargo against GRDP has the strongest correlation value compared to population growth, because the correlation values obtained are greater. Since the results of the regression analysis between GRDP and passengers, baggage and cargo are better than population, the regression equation used for forecasting uses a regression equation between GRDP with passengers, baggage and cargo. The regression equation that obtained will be used as a multiplier for the forecast of passengers, baggage and cargo. This forecasting is done with the following assumptions:

- Normal Conditions: Growth in GRDP of Bandung City uses the average growth value of the period 2003 - 2010, which is $8.00 \%$.

- Optimistic Conditions: Growth in GRDP of Bandung City uses the maximum growth value for the period $2003-2010$, which is $8.45 \%$.

Table 3. Forecasting Passengers in Normal and Optimistic Conditions

\begin{tabular}{|l|r|r|r|r|}
\hline \multirow{2}{*}{ Year } & \multicolumn{2}{|c|}{ PDRB } & \multicolumn{2}{c|}{ Passenger } \\
\cline { 2 - 5 } & \multicolumn{1}{|c|}{ Normal } & Optimistic & Normal & Optimistic \\
\hline 2012 & $36,974.60$ & $37,278.61$ & $1,060,150$ & $1,069,109$ \\
\hline 2013 & $39,934.13$ & $40,427.66$ & $1,147,367$ & $1,161,911$ \\
\hline 2014 & $43,130.55$ & $43,842.72$ & $1,241,565$ & $1,262,553$ \\
\hline 2015 & $46,582.82$ & $47,546.27$ & $1,343,304$ & $1,371,696$ \\
\hline 2016 & $50,311.41$ & $51,562.66$ & $1,453,185$ & $1,490,060$ \\
\hline 2017 & $54,338.46$ & $55,918.33$ & $1,571,862$ & $1,618,421$ \\
\hline 2018 & $58,687.83$ & $60,641.94$ & $1,700,038$ & $1,757,626$ \\
\hline 2019 & $63,385.34$ & $65,764.57$ & $1,838,474$ & $1,908,590$ \\
\hline 2020 & $68,458.84$ & $71,319.92$ & $1,987,990$ & $2,072,306$ \\
\hline 2021 & $73,938.44$ & $77,344.55$ & $2,149,474$ & $2,249,852$ \\
\hline 2022 & $79,856.65$ & $83,878.11$ & $2,323,883$ & $2,442,396$ \\
\hline 2023 & $86,248.55$ & $90,963.57$ & $2,512,253$ & $2,651,204$ \\
\hline 2024 & $93,152.08$ & $98,647.57$ & $2,715,700$ & $2,877,652$ \\
\hline 2025 & $100,608.19$ & $106,980.66$ & $2,935,431$ & $3,123,228$ \\
\hline 2026 & $108,661.10$ & $116,017.68$ & $3,172,751$ & $3,389,549$ \\
\hline 2027 & $117,358.58$ & $125,818.08$ & $3,429,065$ & $3,678,367$ \\
\hline
\end{tabular}


Table 4. Forecasting Baggage and Cargo in Normal and Optimistic Conditions

\begin{tabular}{|c|c|c|c|c|c|c|}
\hline \multirow{2}{*}{ Year } & \multicolumn{2}{|c|}{ PDRB } & \multicolumn{2}{c|}{ Baggage } & \multicolumn{2}{c|}{ Cargo } \\
\cline { 2 - 7 } & Normal & Optimistic & Normal & Optimistic & Normal & Optimistic \\
\hline 2012 & $36,974.60$ & $37,278.61$ & $7,510,525$ & $7,608,022$ & $1,583,069$ & $1,596,555$ \\
\hline 2013 & $39,934.13$ & $40,427.66$ & $8,459,647$ & $8,617,922$ & $1,714,354$ & $1,736,247$ \\
\hline 2014 & $43,130.55$ & $43,842.72$ & $9,484,738$ & $9,713,132$ & $1,856,147$ & $1,887,739$ \\
\hline 2015 & $46,582.82$ & $47,546.27$ & $10,591,880$ & $10,900,858$ & $2,009,290$ & $2,052,028$ \\
\hline 2016 & $50,311.41$ & $51,562.66$ & $11,787,641$ & $12,188,915$ & $2,174,690$ & $2,230,196$ \\
\hline 2017 & $54,338.46$ & $55,918.33$ & $13,079,113$ & $13,585,779$ & $2,353,330$ & $2,423,413$ \\
\hline 2018 & $58,687.83$ & $60,641.94$ & $14,473,957$ & $15,100,640$ & $2,546,268$ & $2,632,952$ \\
\hline 2019 & $63,385.34$ & $65,764.57$ & $15,980,447$ & $16,743,467$ & $2,754,650$ & $2,860,192$ \\
\hline 2020 & $68,458.84$ & $71,319.92$ & $17,607,521$ & $18,525,069$ & $2,979,710$ & $3,106,628$ \\
\hline 2021 & $73,938.44$ & $77,344.55$ & $19,364,829$ & $20,457,168$ & $3,222,785$ & $3,373,880$ \\
\hline 2022 & $79,856.65$ & $83,878.11$ & $21,262,796$ & $22,552,479$ & $3,485,317$ & $3,663,709$ \\
\hline 2023 & $86,248.55$ & $90,963.57$ & $23,312,681$ & $24,824,788$ & $3,768,862$ & $3,978,020$ \\
\hline 2024 & $93,152.08$ & $98,647.57$ & $25,526,644$ & $27,289,046$ & $4,075,102$ & $4,318,882$ \\
\hline 2025 & $100,608.19$ & $106,980.66$ & $27,917,816$ & $29,961,468$ & $4,405,855$ & $4,688,538$ \\
\hline 2026 & $108,661.10$ & $116,017.68$ & $30,500,384$ & $32,859,639$ & $4,763,082$ & $5,089,420$ \\
\hline 2027 & $117,358.58$ & $125,818.08$ & $33,289,667$ & $36,002,628$ & $5,148,903$ & $5,524,166$ \\
\hline
\end{tabular}

Potential flight routes are analyzed from the consideration of the existing routes at Husein Sastranegara Airport, that is the flight schedule for January 2012.
Table 5. Flight route

\begin{tabular}{|c|c|c|}
\hline Routes & $\begin{array}{c}\text { Aircraft } \\
\text { movements in a } \\
\text { week }\end{array}$ & $\begin{array}{c}\% \\
\text { Route }\end{array}$ \\
\hline Bandung-Medan & 10 & $11.91 \%$ \\
\hline Bandung-Surabaya-Denpasar & 7 & $6.12 \%$ \\
\hline $\begin{array}{c}\text { Bandung-Bandar } \\
\text { Lampung-Palembang }\end{array}$ & 6 & $2.60 \%$ \\
\hline Bandung-Semarang & 7 & $3.03 \%$ \\
\hline Bandung-Jogja (MA-60) & 5 & $2.17 \%$ \\
\hline Bandung-Jogja (ATR-72) & 7 & $3.59 \%$ \\
\hline Bandung-Halim Perdana & 7 & $3.03 \%$ \\
\hline Kusuma & 11 & $13.11 \%$ \\
\hline Bandung-Denpasar & 3 & $2.62 \%$ \\
\hline Bandung-Surabaya (B-735) & 7 & $5.36 \%$ \\
\hline Bandung-Surabaya (B-732) & 18 & $21.45 \%$ \\
\hline Bandung-Singapura & 21 & $25.02 \%$ \\
\hline Bandung-Kuala Lumpur & &
\end{tabular}

With the consideration of the above and the development of travel by air transportation, it is planned that service routes in optimistic conditions are as follows. The estimated distribution of passengers and flight routes is shown in Table 6.

Table 6. Passenger Distribution and Flight Routes (Optimistic)

\begin{tabular}{|c|c|c|c|c|}
\hline Route & \multicolumn{4}{|c|}{ Number of Passenger (1 way) } \\
\hline & 2012 & 2017 & 2022 & 2027 \\
\hline Bandung-Medan & 63,666 & 96,378 & 146,307 & 220,880 \\
\hline Bandung-Surabaya- Denpasar & 32,682 & 49,474 & 75,104 & 113,385 \\
\hline Bandung-Bandar Lampung-Palembang & 13,891 & 21,028 & 31,922 & 48,192 \\
\hline Bandung-Semarang & 16,206 & 24,533 & 37,242 & 56,224 \\
\hline Bandung-Jogja (MA-60) & 11,576 & 17,523 & 26,601 & 40,160 \\
\hline Bandung-Jogja (ATR-72) & 19,177 & 29,030 & 44,070 & 66,532 \\
\hline Bandung-Halim Perdana Kusuma & 16,206 & 24,533 & 37,242 & 56,224 \\
\hline Bandung-Denpasar & 70,033 & 106,016 & 160,937 & 242,968 \\
\hline Bandung-Surabaya (B-735) & 14,007 & 21,203 & 32,188 & 48,594 \\
\hline Bandung-Surabaya (B-732) & 28,631 & 43,341 & 65,794 & 99,329 \\
\hline Bandung-Singapura & 114,599 & 173,480 & 263,352 & 397,583 \\
\hline Bandung-Kuala Lumpur & 133,698 & 202,394 & 307,244 & 463,847 \\
\hline
\end{tabular}


Table 7. Annual Aircraft Forecasting

\begin{tabular}{|c|c|c|c|c|}
\hline \multirow{2}{*}{ Aircraft types } & \multicolumn{4}{|c|}{ Number of aircraft (year) } \\
\cline { 2 - 5 } & $\mathbf{2 0 1 2}$ & $\mathbf{2 0 1 7}$ & $\mathbf{2 0 2 2}$ & $\mathbf{2 0 2 7}$ \\
\hline A-320 & 4,992 & 7,956 & 11,648 & 16,640 \\
\hline ATR-72 & 364 & 364 & 728 & 728 \\
\hline B-732 & 364 & 364 & 364 & 364 \\
\hline B-735 & 520 & 520 & 884 & 1,404 \\
\hline MA-60 & 1,300 & 1,300 & 2,340 & 3,328 \\
\hline
\end{tabular}

The conditions used in annual aircraft forecasting are optimistic conditions. The type of aircraft used is an aircraft that operates at the airport (January 2012) and is assumed to have no additional or reduced routes. The assumption of the proportion of aircraft use is based on the analysis of the flight routes that have been calculated previously.

The analysis shows that the annual aircraft that will be dominant in the future are Airbus A320 aircraft.

The forecast of the number of goods and post served by the airport is carried out at the generate level analysis method. The calculation of the need for freight transport aircraft is analyzed based on excess goods that can be transported by commercial passenger aircraft. The assumption used is the carrying capacity of commercial aircraft cargo is $10 \%$ of the maximum pay load.

Table 8. Commercial Aircraft Freight Capacity

\begin{tabular}{|c|c|}
\hline Aircraft types & Capacity (Kg) \\
\hline A-320 & 7250 \\
\hline B-735 & 5960 \\
\hline B-732 & 5720 \\
\hline MA-60 & 2180 \\
\hline ATR-72 & 2110 \\
\hline
\end{tabular}

Table 9. Sharing of Passenger Aircraft

\begin{tabular}{|c|c|c|c|c|}
\hline Year & $\begin{array}{c}\text { Baggage and } \\
\text { Cargo } \\
\text { Projection } \\
(\mathrm{kg})\end{array}$ & $\begin{array}{c}\text { Sharing of } \\
\text { Passenger } \\
\text { Aircraft }(\mathrm{kg})\end{array}$ & Overload & $\begin{array}{c}\text { Cargo } \\
\text { aircraft }\end{array}$ \\
\hline 2012 & $4,602,289$ & $31,403,320$ & $(26,801,031)$ & - \\
\hline 2017 & $8,004,596$ & $31,403,320$ & $(23,398,724)$ & - \\
\hline 2022 & $13,108,094$ & $31,403,320$ & $(18,295,226)$ & - \\
\hline 2027 & $20,763,397$ & $31,403,320$ & $(10,639,923)$ & - \\
\hline
\end{tabular}

From table 9, it can be concluded that the need for cargo aircraft in the forecast year is not yet needed, because the sharing of commercial aircraft used is still able to carry goods and posts. This means that goods can still be served by passenger aircraft.

Calculation of peak hour passengers carried by Theoretical Methods. This forecasting aims to determine the distribution of passengers especially during peak hour in the future. Besides, this forecasting is used as data to determine the number of aircraft during peak hour. The summary of passenger peak hour forecast results can be seen in Table 10.

Table 10. Passenger Peak Hour (1 way)

\begin{tabular}{|c|c|c|c|c|c|}
\hline \multicolumn{6}{|c|}{ Optimistic Conditions - Domestic } \\
\hline \multicolumn{2}{|l|}{ Routes } & 2012 & 2017 & 2022 & 2027 \\
\hline \multicolumn{2}{|c|}{ Bandung-Medan } & 121 & 183 & 278 & 419 \\
\hline \multicolumn{2}{|c|}{ Bandung-Surabaya-Denpasar } & 124 & 188 & 285 & 430 \\
\hline \multicolumn{2}{|c|}{$\begin{array}{c}\text { Bandung-Bandar } \\
\text { Lampung-Palembang }\end{array}$} & 53 & 80 & 121 & 183 \\
\hline \multicolumn{2}{|c|}{ Bandung-Semarang } & 133 & 141 & 141 & 213 \\
\hline \multicolumn{2}{|c|}{ Bandung-Jogja } & 58 & 88 & 134 & 203 \\
\hline \multicolumn{2}{|c|}{$\begin{array}{c}\text { Bandung-Halim Perdana } \\
\text { Kusuma }\end{array}$} & 62 & 93 & 141 & 213 \\
\hline \multicolumn{2}{|c|}{ Bandung-Denpasar } & 133 & 201 & 305 & 461 \\
\hline \multicolumn{2}{|c|}{ Bandung-Surabaya } & 81 & 123 & 186 & 281 \\
\hline \multicolumn{6}{|c|}{ Optimistic Conditions - International } \\
\hline Route & 2012 & 2017 & 2022 & \multicolumn{2}{|c|}{2027} \\
\hline Bandung-Singapura & 145 & 220 & 333 & \multicolumn{2}{|c|}{503} \\
\hline $\begin{array}{l}\text { Bandung-Kuala } \\
\text { Lumpur }\end{array}$ & 169 & 256 & 389 & \multicolumn{2}{|c|}{587} \\
\hline
\end{tabular}

Analysis of aircraft peak hour is carried out, that is the number of passengers during peak hour on aircraft operating at Husein Sastranegara Airport using theoretical methods. The limitation of analysis is the plan load factor of $70 \%-90 \%$. The results of calculations using theoretical methods can be seen in Table 11 .

Tabel 11. Aircraft Peak Hour (1 way)

\begin{tabular}{|c|c|c|c|c|c|}
\hline \multicolumn{6}{|c|}{ Optimistic Conditions - Domestic } \\
\hline Routes & $\begin{array}{c}\text { Aircraft } \\
\text { Types }\end{array}$ & 2012 & 2017 & 2022 & 2027 \\
\hline $\begin{array}{l}\text { Bandung - } \\
\text { Medan }\end{array}$ & A 320 & 1 & 1 & 1 & 2 \\
\hline $\begin{array}{c}\text { Bandung - } \\
\text { Surabaya - } \\
\text { Denpasar }\end{array}$ & В 735 & 1 & 1 & 2 & 3 \\
\hline $\begin{array}{l}\text { Bandung - } \\
\text { Medan - } \\
\text { Palembang }\end{array}$ & MA 60 & 1 & 1 & 2 & 2 \\
\hline $\begin{array}{l}\text { Bandung - } \\
\text { Denpasar }\end{array}$ & A 320 & 1 & 1 & 2 & 2 \\
\hline $\begin{array}{l}\text { Bandung - } \\
\text { Semarang }\end{array}$ & MA 60 & 1 & 1 & 2 & 3 \\
\hline $\begin{array}{l}\text { Bandung - } \\
\text { Surabaya }\end{array}$ & B 735 & 1 & 1 & 1 & 1 \\
\hline $\begin{array}{c}\text { Bandung - } \\
\text { Surabaya }\end{array}$ & В 732 & 1 & 1 & 1 & 1 \\
\hline $\begin{array}{l}\text { Bandung - } \\
\text { Jogja }\end{array}$ & MA-60 & 1 & 1 & 1 & 1 \\
\hline $\begin{array}{l}\text { Bandung - } \\
\text { Jogja }\end{array}$ & ATR-72 & 1 & 1 & 1 & 1 \\
\hline $\begin{array}{l}\text { Bandung - } \\
\text { Halim Perdana } \\
\text { Kusuma }\end{array}$ & MA-60 & 1 & 1 & 2 & 3 \\
\hline \multicolumn{6}{|c|}{ Optimistic Conditions - International } \\
\hline Routes & $\begin{array}{c}\text { Aircraft } \\
\text { Types }\end{array}$ & 2012 & 2017 & 2022 & 2027 \\
\hline $\begin{array}{l}\text { Bandung - } \\
\text { Singapura }\end{array}$ & A-320 & 1 & 1 & 2 & 2 \\
\hline $\begin{array}{l}\text { Bandung - } \\
\text { Kuala Lumpur }\end{array}$ & A-320 & 1 & 1 & 2 & 3 \\
\hline
\end{tabular}


The results of the passenger peak hour analysis show that in 2012 until 2017, there was no increase in the number of aircraft during peak hour. While for the years 2022 and 2027 , there has been an increase in the number of aircraft.[4]

\subsection{Apron Analysis}

From the results of forecasting analysis at peak hour, it was obtained recapitulation of the number of aircraft that existed at certain hours. Then the results of the recapitulation are entered into the assumed flight schedule and route. The results of the analysis will show the number of aircraft parked at certain hours. Analysis carried out for 2012, 2017, 2022 and 2027. So that we can know the needs of the apron area needed for each forecasting year.
From the results of the analysis of Husein Sastranegara airport traffic based on the assumption that the flight schedule is effective in January 2012 with an interval of every 30 minutes, it shows that during the operation of the airport in one day there is no maximum density at the apron. This is indicated by the accumulation of aircraft that do not exceed 4 aircraft in 1 hour. Even the highest aircraft accumulation occurred after the completion of airport operations. Staying aircraft/ RON (remain over night) at the airport for tomorrow's flight as much as 5 aircraft. This condition will be used as the basis for forecasting the capacity of the apron in terms of the number of parking stands needed, that is when the parking stand is used most.

The following is an analysis table of apron capacity based on flight schedules in terms of the number of stand parking per day in 1 week for 2012, 2017, 2022 and 2027.

Table 12. Analysis of Husein Sastranegara Airport Traffic in 1 Day

\begin{tabular}{|c|c|c|c|c|c|}
\hline \multicolumn{2}{|c|}{ Time } & \multirow[t]{2}{*}{ In } & \multirow[t]{2}{*}{ Out } & \multirow[t]{2}{*}{ Accumulate } & \multirow[t]{2}{*}{ Volume } \\
\hline $5: 00$ & $5: 30$ & & & & \\
\hline $5: 30$ & $6: 00$ & 5 & 1 & 4 & 5 \\
\hline $6: 00$ & $6: 30$ & & 1 & 3 & 5 \\
\hline $6: 30$ & $7: 00$ & & & 3 & 5 \\
\hline $7: 00$ & $7: 30$ & & & 3 & 5 \\
\hline $7: 30$ & $8: 00$ & & 2 & 1 & 5 \\
\hline $8: 00$ & $8: 30$ & 1 & 1 & 1 & 6 \\
\hline $8: 30$ & 9:00 & 1 & & 2 & 7 \\
\hline 9:00 & $9: 30$ & 1 & 1 & 2 & 8 \\
\hline $9: 30$ & 10:00 & & 1 & 1 & 8 \\
\hline 10:00 & $10: 30$ & & & 1 & 8 \\
\hline $10: 30$ & 11:00 & 1 & & 2 & 9 \\
\hline 11:00 & $11: 30$ & 1 & 1 & 2 & 10 \\
\hline $11: 30$ & 12:00 & & 1 & 1 & 10 \\
\hline 12:00 & $12: 30$ & 1 & & 2 & 11 \\
\hline $12: 30$ & 13:00 & & 1 & 1 & 11 \\
\hline 13:00 & $13: 30$ & & & 1 & 11 \\
\hline $13: 30$ & 14:00 & 2 & & 3 & 13 \\
\hline 14:00 & $14: 30$ & & 1 & 2 & 13 \\
\hline $14: 30$ & 15:00 & & & 2 & 13 \\
\hline 15:00 & $15: 30$ & 2 & & 4 & 15 \\
\hline $15: 30$ & 16:00 & & 1 & 3 & 15 \\
\hline 16:00 & $16: 30$ & & 1 & 2 & 15 \\
\hline $16: 30$ & $17: 00$ & 2 & 1 & 3 & 17 \\
\hline 17:00 & $17: 30$ & & & 3 & 17 \\
\hline $17: 30$ & 18:00 & 1 & 1 & 3 & 18 \\
\hline 18:00 & 18:30 & & 1 & 2 & 18 \\
\hline $18: 30$ & 19:00 & & & 2 & 18 \\
\hline 19:00 & 19:30 & & & 2 & 18 \\
\hline 19:30 & $20: 00$ & 1 & 1 & 2 & 19 \\
\hline $20: 00$ & $20: 30$ & 1 & & 3 & 20 \\
\hline $20: 30$ & 21:00 & 1 & & 4 & 21 \\
\hline 21:00 & $21: 30$ & & & 4 & 21 \\
\hline $21: 30$ & 22:00 & 1 & & 5 & 22 \\
\hline \multirow[t]{2}{*}{ 22:00 } & $22: 30$ & & & 5 & 22 \\
\hline & Total & 22 & 17 & & \\
\hline
\end{tabular}


Table 13. Apron Capacity Analysis in 2012 and 2017

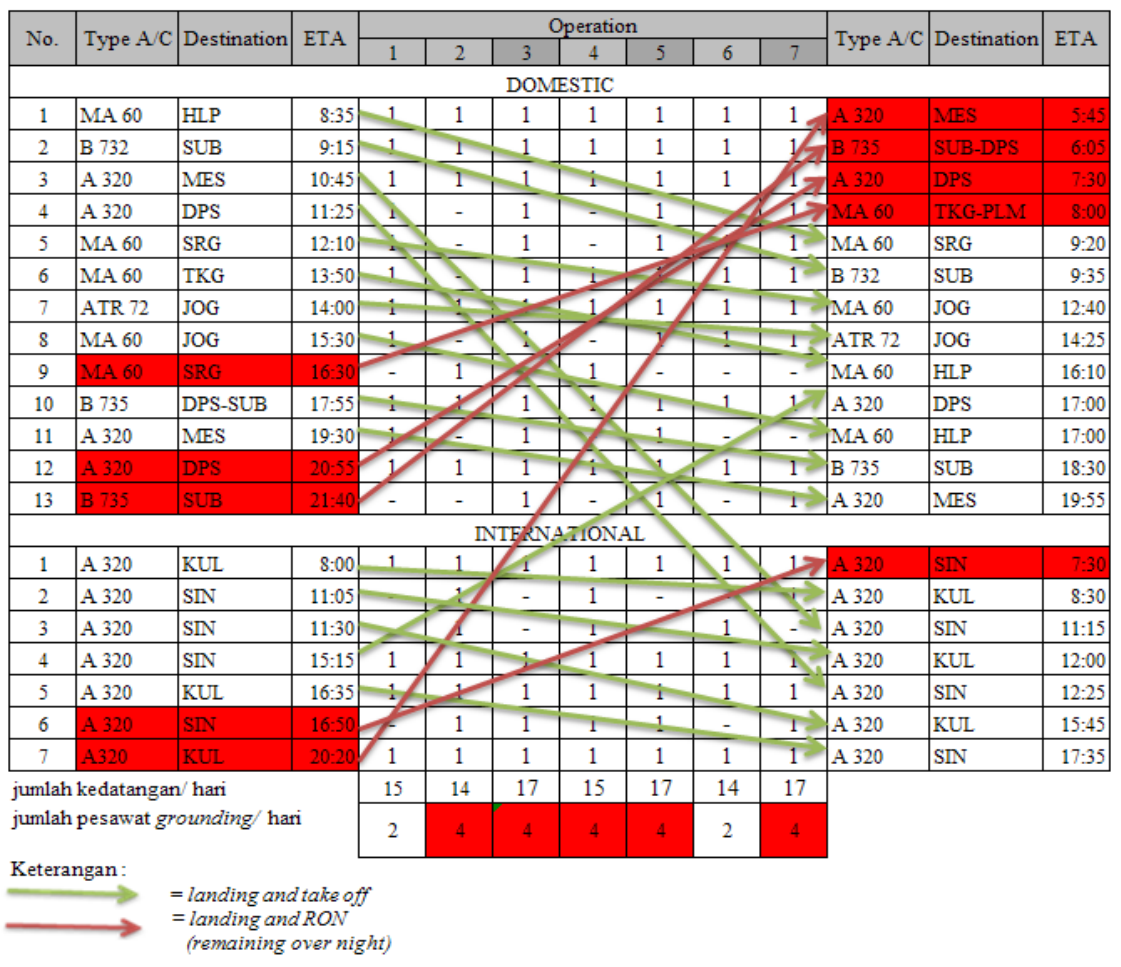

Table 14. Apron Capacity Analysis in 2022

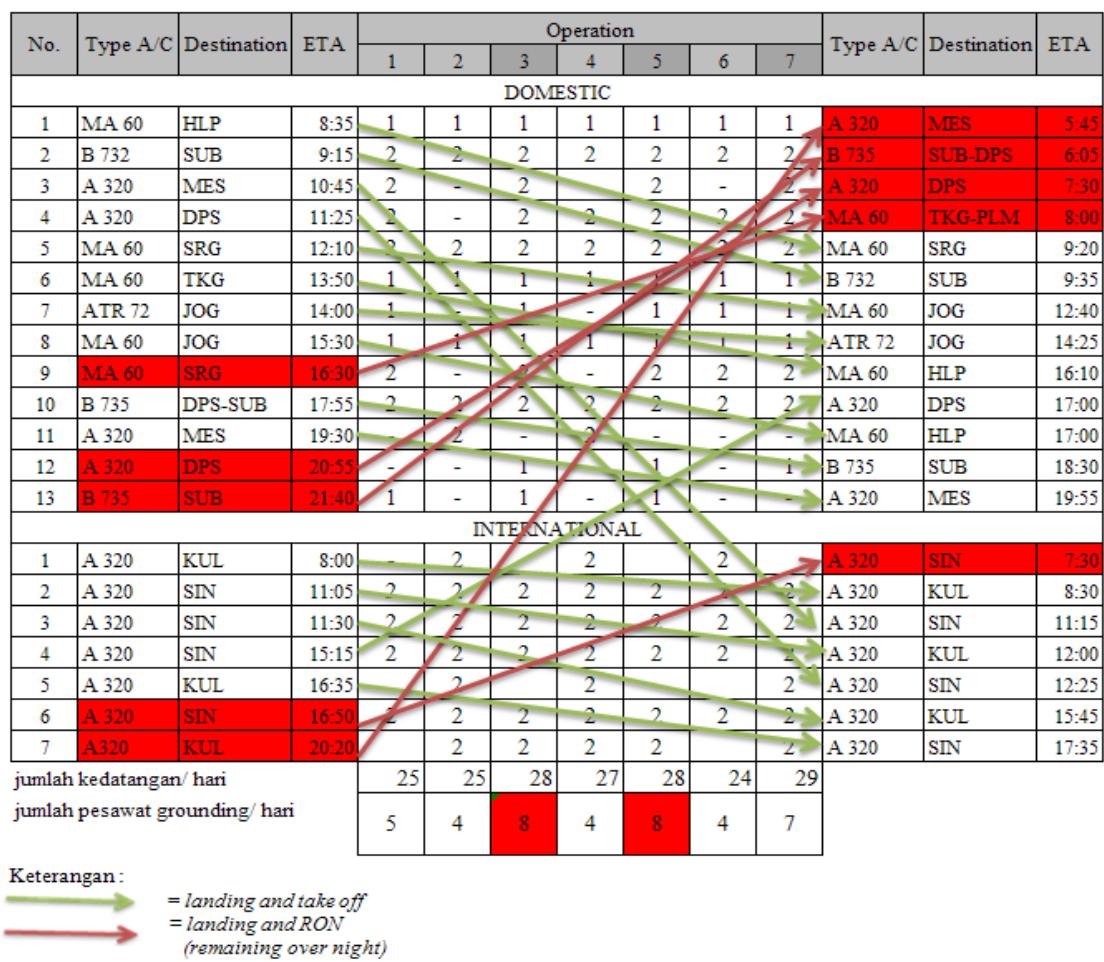


Table 15. Apron Capacity Analysis in 2027

\begin{tabular}{|c|c|c|c|c|c|c|c|c|c|c|c|c|c|}
\hline \multirow{2}{*}{ No. } & \multirow{2}{*}{ Type A/C } & \multirow{2}{*}{ Destination } & \multirow{2}{*}{ ETA } & \multicolumn{7}{|c|}{ Operation } & \multirow{2}{*}{ Type A/C } & \multirow{2}{*}{ Destination } & \multirow{2}{*}{ ETA } \\
\hline & & & & 1 & 2 & 3 & 4 & 5 & 6 & 7 & & & \\
\hline \multicolumn{14}{|c|}{ DOMESTIC } \\
\hline 1 & MA 60 & HLP & $8: 35$ & & 2 & 2 & 2 & 2 & 2 & 2 & A 320 & MES & $5: 45$ \\
\hline 2 & B 732 & SUB & $9: 15$ & & & 3 & 3 & 3 & 3 & 34 & B 735 & SUB-DPS & $6: 05$ \\
\hline 3 & A 320 & MES & $10: 45$ & & & 2 & & 2 & - & - & A 320 & DPS & $7: 30$ \\
\hline 4 & A 320 & DPS & $11: 25$ & & - & 2 & 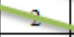 & & & & MA 60 & TKG-PLM & $8: 00$ \\
\hline 5 & MA 60 & SRG & $12: 10$ & & 3 & 3 & 3 & & & 3 & MA 60 & SRG & $9: 20$ \\
\hline 6 & MA 60 & TKG & $13: 50$ & & & & & & 1 & 1 & B 732 & SUB & $9: 35$ \\
\hline 7 & ATR 72 & JOG & $14: 00$ & & & & & & 1 & $i$ & MA 60 & JOG & $12: 40$ \\
\hline 8 & MA 60 & JOG & $15: 30$ & & & & & & & i) & ATR 72 & JOG & $14: 25$ \\
\hline 9 & MA 60 & SRG & 16:30 & & & & & 3 & 3 & 3 & MA 60 & HLP & $16: 10$ \\
\hline 10 & B 735 & DPS-SUB & $17: 55$ & & & & & & 2 & 27 & A 320 & DPS & $17: 00$ \\
\hline 11 & A 320 & MES & $19: 30$ & & & & & & & & MA 60 & HLP & $17: 00$ \\
\hline 12 & A 320 & DPS & $20: 55$ & & 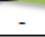 & & & & & & B 735 & SUB & $18: 30$ \\
\hline 13 & B 735 & SUB & 21:40 & & - & & - & & & \pm & A. 320 & MES & 19:55 \\
\hline & & & & & & & & & & & & & \\
\hline 1 & A 320 & KUL & $8: 00$ & & 2 & 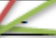 & 2 & - & 2 & $\rightarrow$ & A 320 & SIN & $7: 30$ \\
\hline 2 & A 320 & SIN & $11: 05$ & & 3 & 3 & 3 & 3 & & & A 320 & KUL & $8: 30$ \\
\hline 3 & A 320 & SIN & $11: 30$ & & 2 & & 2 & 2 & 2 & 2 & A 320 & $\operatorname{SIN}$ & $11: 15$ \\
\hline 4 & A 320 & SIN & $15: 15$ & 3 & 2 & & 3 & 3 & 3 & 3 & A 320 & KUL & $12: 00$ \\
\hline 5 & A 320 & KUL & $16: 35$ & & 2 & & 2 & 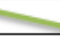 & & 2 & A 320 & SIN & $12: 25$ \\
\hline 6 & A 320 & SIN & $16: 50$ & & 3 & 3 & 3 & 3 & 3 & 31 & A 320 & KUL & $15: 45$ \\
\hline 7 & A320 & KUL & $20: 20$ & & 2 & 2 & 2 & 2 & & 2 & A 320 & SIN & $17: 35$ \\
\hline \multirow{2}{*}{\multicolumn{4}{|c|}{$\begin{array}{l}\text { jumlah kedatangan/ hari } \\
\text { jumlah pesawat grounding/ hari }\end{array}$}} & 32 & 32 & 35 & 34 & 35 & 31 & 36 & & & \\
\hline & & & & 7 & 5 & 10 & 5 & 10 & 6 & 9 & & & \\
\hline \multicolumn{14}{|c|}{ Keterangan : } \\
\hline
\end{tabular}

Based on the table 15, the density of aircraft on the apron is indicated by the number of aircraft staying or RON (remain over night), which amounts to 10 aircraft in 1 day (analysis in 2027). Aircraft density at the apron occurs after the completion of airport operations, that is staying aircraft or RON (remain over night) for tomorrow's departure, as listed in the tables 13 to 15 .

\section{Conclusions and Suggestions}

Based on the analysis and discussion at the apron of Husein Sastranegara Airport, it can be concluded as follows:

1. Apron capacity up to the planned year of 2022 can still serve especially staying aircraft or RON (remain over night). However, that year is the maximum capacity of the apron.

2. For the planned year of 2027, the apron cannot service all aircraft staying overnight, because the number of aircraft staying over exceeds the number of available parking stands.

Some suggestions that can be proposed as references in future studies and as a reference for PT. Angkasa Pura is [2]:

1. Making a Remote Apron or adding a parking stand Because in the planned year 2022 the apron capacity has reached a maximum, it is necessary to make a Remote Apron or the addition of a parking stand. Its function is to anticipate the presence of staying aircraft or RON (remain over night) at Husein Sastranegara Airport. Alternatively, the Remote Apron location or parking stand can be placed in front of the hangar owned by PT. Dirgantara Indonesia.

2. Add signs (marking) to the apron, namely:

- Service Road Marking

Its function is to limit the service road area, which allows the movement of separate Ground Service Equipment (GSE) by aircraft.

- $\quad$ Equipment Parking Area Marking

Its function is to limit aircraft to areas designated as parking lots for aircraft ground service equipment or parking lots for Ground Service Equipment (GSE).

3. The addition of a mobile lounge for operational up and down passengers from the terminal to the aircraft, especially during rainy weather. This is necessary because the terminal distance and apron parking stand are quite far away.

4. Standard aircraft clearance requirements for buildings are in accordance with applicable regulations.

5. Construction of a hydrant fuel pump and ground electricity support to reduce ground service operations around the aircraft. 


\section{Acknowledgements}

The authors would like express their sincere appreciations to the following organizations and individuals:

- Faculty of Civil Engineering, Universitas Jenderal Achmad Yani

- Dr. Ferry Rusgiyarto, Ir., M.T. (Universitas Jenderal Achmad Yani)

- Hendro Tri Yuliyanto, S.T. (Universitas Jenderal Achmad Yani)

\section{REFERENCES}

[1] Aerodrome Design Manual. 2005. Part 2. International Civil Aviation Organization.

[2] Jabarullah, N.H., Shabbir, M.S., Abbas, M., Siddiqi, A.F. \& Berti, S. (2019) Using random inquiry optimization method for provision of heat and cooling demand in hub systems for smart buildings, Sustainable Cities and Society, 47, 101475.

[3] Nahar, A. K., Abdalla, A. N., Jaber, A. Y., \& Ezzaldean, M. M. (2017). PAPR Reduction Using Eight Factors Rotating Phase Shift Technique Based on Local Search Algorithm in OFDM. Review of Computer Engineering Research, 4(2), 38-53.

[4] Nahar, A. K., Gitaffa, S. A., Ezzaldean, M. M., \& Khleaf, H. K. (2017). FPGA implementation of MC-CDMA wireless communication system based on SDR-a review. Review of Information Engineering and Applications, 4(1), 1-19. 